\title{
Moral Ecology of a Forest: The Nature Industry and Maya Post- Conservation. By José Martínez-Reyes. 2016. University of Arizona Press, Tucson. 216 pp.
}

\author{
Eugene N. Anderson ${ }^{1 *}$ \\ ${ }^{1}$ Department of Anthropology, University of California Riverside, USA. \\ *eugene.anderson@ucr.edu
}

Received September 21, 2017

Accepted September 21, 2017

OPEN ӘACCESS

DOI 10.14237/ebl.8.1.2017.1119

Copyright (C) 2017 by the author(s) licensee Society of Ethnobiology. This is an open-access article distributed under the terms of the Creative Commons Attribution-NonCommercial 4.0 International Public License (https://creativecommons.org/licenses/by-nc/4.0), which permits non-commercial use, distribution, and reproduction in any medium, provided the original author and source are credited.

"Moral ecology" is a term recently coined in parallel with the term "moral economy." It certainly is the right term for the resource management strategies of the Yucatec Maya, for whom proper dealings with plants, animals, and the landscape is at the heart of ethical and moral behavior.

José Martínez-Reyes has worked for many years in the tiny, isolated community of Tres Reyes, Quintana Roo, Mexico. This community has the bad luck to be situated on the border of the vast Sian $\mathrm{Ka}$ 'an nature reserve, a major biosphere reserve and a point of pride for Quintana Roo. Tres Reyes depends on milpa agriculture, plant gathering, and hunting, and thus affects the forest next to and even within the reserve. This has put it in the sights of government agencies and NGOs who try to prevent or regulate farming, hunting, and other local activities. Like other traditional Maya, the people of Tres Reyes have a thoroughly sustainable system, supported by ethical and religious teachings that range from careful fire control when the milpa is burned to taking no more animals than the game herds can spare. Ceremonies that have lapsed in more modern communities, such as the ch'a chaak to bring rain and the loj ts'oon to renew hunting luck (which involves minimizing overhunting), still serve to keep Tres Reyes in balance with its surroundings.

All this has meant little to outside agencies, which follow a typical pattern: a project—often good in concept, but poorly planned and implemented-is imposed on the local people. Some initial funding is provided, but not maintained. The local people try to adapt, but no one listens to them or attends to their actual situation, needs, or capabilities. The plan thus fails, and is forgotten. Meanwhile, Tres Reyes continues to exist in substantial poverty. In 2009, the community barred further action by NGOs, but cannot stop annoying and erratic interference by Mexican government agencies.

José Martínez-Reyes' findings are similar to many of those who have worked in nearby communities, including: Ueli Hostetler (1996), Amber O'Connor (O'Connor and Anderson 2017), and myself (Anderson 2005; Anderson and Medina Tzuc 2005), among others. Hostetler describes the resulting "project fatigue" caused by the pattern mentioned above.

Having worked over a 25 -year period in nearby Chunhuhub, I can testify to José Martínez-Reyes' accuracy and insight. He is a first-rate ethnographer with a solid command of languages, previous research, and the field situation. I know Tres Reyes somewhat, know some of the people Martínez-Reyes mentions, and followed some of the plans and NGO activities he discusses. Occasionally I know some back stories; for instance, he discusses the heavy hand of the Amigos de Sian Ka'an ("Friends of the Sian Ka'an Reserve") as one of the heavy-handed, clueless NGOs. I recall that at first this was an idealist local group with sensible ideas, but the local leadership was muscled out by remote bureaucrats, leading to the problems Martínez-Reyes accurately describes.

$\mathrm{He}$ provides an excellent and well-organized theoretical framework drawn from literature on ethnoecology, moral economy, moral ecology, and critical studies of conservation. Especially useful is 
recent Latin American thought, such as the work of Arturo Escobar, Enrique Leff, and Victor Toledo, who have described similar situations and theorized the conflict between powerful but ignorant government or nongovernmental groups and less powerful but far more aware people on the land. The critical work of writers like James Igoe and Dan Brockington is also important.

Martínez-Reyes sees much of the problem as "neoliberalism," but only an attempted land grab by a local millionaire was "neoliberal" in the usual sense of the term (i.e., private enterprise run amok). The rest of the problem is better seen through Max Weber's view of bureaucracy: a powerful, impersonal force, taking on a life of its own, often intruding on local agency. James Scott's writings on the dysfunctions of modern states (notably Scott 1998) are useful here. Ethnobiologists will not only profit from the tight, well-constructed theoretical framework herein, but from the superb descriptions of hunting and milpa making.

The future is cloudy. "Post-conservation" might well mean no conservation-instead, the progressive destruction of the forest and agricultural system as is happening widely in the Yucatan Peninsula today. Hunting is almost certainly unsustainable now in the Tres Reyes area, despite ceremonies. The game is thoroughly shot out of most of the Yucatan Peninsula, and Yucatan state has saved its deer only by truly draconian conservation measures. Better management will come only when government agencies listen to local people, take them and their knowledge seriously, and invest time on the ground working with communities. Such a future is currently unlikely, given the rush to turn all of Quintana Roo into a macro-Cancun.

Having done research in the area, I am extremely glad to see an excellent ethnography that makes major theoretical contributions as well as practical applications.

\section{References Cited}

Anderson, E. N. 2005. Political Ecology of a Yucatec Maya Community. University of Arizona Press, Tucson, AZ.

Anderson, E. N., and F. M. Tzuc. 2005. Animals and the Maya in Southeast Mexico. University of Arizona Press, Tucson, AZ.

Hostetler, U. 1996. Milpa Agriculture and Economic Diversification: Socioeconomic Change in a Maya Peasant Society of Central Quintana Roo, 19001990s. Doctoral Dissertation, University of Berne, Switzerland. Available from University Microfilm International Dissertation Express (UMI No. 9701056).

O'Connor, A., and E. N. Anderson. 2017. K'oben: Three Thousand Years of the Maya Hearth. Rowman and Littlefield, Lanham, MD.

Scott, J. 1998. Seeing Like a State. Yale University Press, New Haven, CT. 